\title{
European Heart Failure 2011
}

Evropský kongres srdečního selhání - Heart Failure 2011, organizovaný Heart Failure Association při Evropské kardiologické společnosti, se konal ve dnech 21. 5. až 24. 5. 2011 v kongresovém centru ve švédském Göteborgu. Kongres byl organizován formou přehledových přednášek, symposií a posterových sdělení původních vědeckých prací.

V sobotním programu dne 21. 5. 2011 byl před slavnostním zahájením kongresu tradičně prostor pro symposia. Velký zájem vzbudilo symposium věnované biomarkerům srdečního selhání se zaměřením na galectin-3. Galectin-3 je protein secernovaný aktivovanými makrofágy a hraje důležitou úlohu v rozvoji fibrózy při tkáňovém poškození. Experimentální práce prokázaly zvýšenou koncentraci galectinu-3 při srdeční hypertrofii a v modelech srdečního selhání. Klinické studie prokázaly aditivní prognostický význam stanovení galectinu-3 spolu s NT-proBNP u akutního srdečního selhání. Výsledky studií, které prokázaly prognostický význam stanovení galectinu-3 u srdečního selhání, komentoval prof. van Veldhuisen z Nizozemska. V následující přednášce pak prof. Cleland z Velké Británie zdůraznil význam galectinu-3 při hodnocení účinnosti terapie chronického srdečního selhání (CHSS). Ukázal, že např́klad ve studii CARE-HF nebyl př́znivý pokles proBNP po zahájení srdeční resynchronizační léčby následován poklesem koncentrací galectinu-3. Toto symposium ukončil prof. Zannad z Francie sdělením na téma léčby chronického srdečního selhání rízené podle koncentrace galectinu-3. Ve výzkumu jsou látky, které inhibují účinek galectinu-3 (známý je účinek antagonisty aldosteronu eplerenonu), látky inhibující aktivitu galectinu-3 a nové látky blokující jeho produkci. ${ }^{1-4}$

V nedělním programu dne 22. 5. 2011 měl velkou návštěvnost blok přednášek věnovaný výběru pacientů pro srdeční resynchronizační terapii. Prof. K. Dickstein z Norska podal aktualizovaný přehled doporučení pro implantaci př́strojů pro srdeční resynchronizační léčbu (CRT). Uvedl, že jednoznačnou indikací pro CRT s implantací defibrilátoru (CRT-D) u nemocných se systolickou dysfunkcí levé komory srdeční a širokým QRS komplexem s již optimalizovanou farmakoterapií je CHSS funkční třídy NYHA III a IV. Novinkou je, že podmínkou zavedení CRT-D již není dilatace levé komory a pacienti tř́dy NYHA IV mohou být ambulantní. Prof. Dickstein komentoval i výsledky studií CRT-D u pacientů $s$ méně symptomatickým CHSS třídy NYHA II (MADIT-CRT, REVERSE a RAFT). Tyto studie dokumentovaly př́znivý dopad CRT-D na mortalitu nemocných s mírným srdečním selháním, se sinusovým rytmem, ejekční frakcí levé komory (EFLK) $\leq 35 \%$ a šírí komplexu QRS $\geq 150$ ms. U pacientů s CHSS a permanentní fibrilací síní bylo zjištěno, že provedení neselektivní ablace a-v junkce po zavedení CRT-D má rovněž příznivý dopad na mortalitu, zatímco dopad CRT-D bez provedení ablace a-v junkce na mortalitu je srovnatelný s implantací defibrilátoru.

$\mathrm{V}$ další přednášce se prof. Willems z Belgie věnoval nákladové efektivitě CRT-D po zveřejnění výsledků studií pacientů s mírným srdečním selháním. Znovu komentoval výsledky studie RAFT, které byly poprvé prezentovány na podzimním setkání American Heart Association 2010. Ve studii RAFT bylo 1798 pacientů s CHSS převážně funkční třídy NYHA II, s EFLK $\leq 30 \%$ a šiří komplexu QRS $\geq 120$ ms, léčených optimální farmakoterapií, randomizováno bud' k léčbě CRT-D, nebo pouze $\mathrm{k}$ zavedení automatického defibrilátoru (ICD). Primárním sledovaným ukazatelem byl dopad léčby na kombinovaný výsledek, tj. celkovou mortalitu a hospitalizace pro srdeční selhání. Průměrný věk pacientů byl 66 let a $83 \%$ bylo mužů. Ve skupině CRT-D byl ve srovnání $s$ ICD nižší výskyt primárních ukazatelů po průměrné době sledování 40 měsíců (33,2\% vs. $40,3 \% ; p=0,0002)$. Analýza podskupin nenalezla rozdíl mezi méně a více symptomatickými pacienty ani rozdíl u nemocných s ischemickou a neischemickou srdeční dysfunkcí. Největší dopad na snížení rizika však byl zjištěn u pacientů s QRS $\geq 150 \mathrm{~ms}$ a EFLK $\leq 20 \%$, naproti tomu u nemocných s fibrilací síní $(n=229)$ nebyl mezi oběma léčebnými postupy nalezen významný rozdíl. Výsledky studie RAFT byly zařazeny do metaanalýzy studií CRT, která dokumentovala příznivý dopad CRT na mortalitu pacientů s CHSS, sinusovým rytmem a širokým komplexem QRS ve funkčních třídách NYHA II, III a IV, a byla podkladem aktualizace doporučení Evropské kardiologické společnosti pro přístrojovou léčbu srdečního selhání. Prof. Willems přednášku uzavřel s tím, že navzdory větším nákladům spojeným s komplikacemi implantace př́stroje CRT-D, jako je dislokace levokomorové elektrody nebo disekce koronárního sinu, které se např́klad ve studii RAFT vyskytly v poměru $14 \%$ pro CRT-D a $6 \%$ pro ICD $(\mathrm{p}<0,001)$, zůstává z pohledu nákladů na počet zachráněných životů CRT-D cenově efektivní. Poslední přednáškou tohoto bloku bylo sdělení prof. Cowieho o významu diagnostické informace př́strojové léčby chronického srdečního selhání.

Moderní přístroje zajištují diagnostiku několika parametrů: arytmií, variability tepové frekvence, hrudní impedance a aktivity pacienta. Je známo, že např́íklad vzestup tepové frekvence monitorované prŕstrojem (ICD nebo CRT) je spojen se zvýšeným rizikem hospitalizace a úmrtí. Hodnocení změny hrudní impedance v čase funkcí tzv. OptiVol umožňuje sledovat riziko akumulace tekutin, dopad této změny na riziko úmrtí a hospitalizace je předmětem hned několika studií (FAST, SENSE-HF, PARTNERS-HF). ${ }^{5-8}$

Dalším hojně navštíveným blokem přednášek byla dne 22. 5. 2011 sekce věnovaná CHSS a chronické obstrukční plicní nemoci (CHOPN). V úvodní přednášce hovořil prof. Hawkins z Velké Británie o vztahu mezi CHSS a CHOPN z pohledu epidemiologie. Prevalence CHOPN u pacientů s CHSS se na základě studie 374000 pacientů primární péče ve Velké Británii odhaduje na $24 \%$, u nekuřáků s CHSS na $17 \%$, ale u kuřáků na více než 29 \%! Tato data jsou ve shodě s výsledky kohortových studií pacientů s CHSS v USA, kde odhad prevalence CHOPN je 25-30 \% s rostoucí incidencí. Ukazuje se, že výskyt CHOPN je vyšší u pacientů se srdečním selháním a zachovalou EFLK. CHOPN je nezávislým rizikovým faktorem úmrtí pacientů s CHSS v jednom roce (hazard ratio [HR] 1,39). Naproti tomu, přítomnost srdečního selhání zvyšuje riziko úmrtí 


\begin{tabular}{|c|c|c|c|c|c|c|}
\hline Studie & 0,1 & 0,2 & 0,5 & & 1 & Odds ratio \\
\hline MIRACLE 2002 & & & & $\phi$ & & 0,73 \\
\hline COMPANION 2004 & & & & - & & 0,81 \\
\hline REVERSE 2008 & & & & 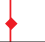 & & 0,78 \\
\hline MADIT CRT 2009 & & & & - & & 0,93 \\
\hline $\begin{array}{l}\text { CARE-HF } 2006 \\
\text { Extended follow-up }\end{array}$ & & & - & & & 0,53 \\
\hline RAFT 2010 & & & & 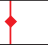 & & 0,74 \\
\hline \multirow[t]{2}{*}{ Souhrn (pooled data) } & & & & 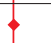 & & 0,74 \\
\hline & 0,1 & 0,2 & 0,5 & & 1 & 2 \\
\hline
\end{tabular}

Obrázek 1 Metaanalýza: vliv CRT na mortalitu pacientů s chronickým srdečním selháním QRS (SR)

pacientů s CHOPN (HR 2,1); u nemocných s CHOPN je vysoká prevalence srdeční dysfunkce a srdeční selhání u nich často zůstává nerozpoznáno.

V následujících sděleních hovořili prof. Rutten z Nizozemska o významu a obtížích diagnózy srdečního selhání u pacientů s CHOPN a $d r$. Clark z Velké Británie o dušnosti jako společném příznaku CHSS a CHOPN. Diagnostika srdečního selhání je u osob s CHOPN často obtížná, limitující může být např́klad špatná echokardiografická vyšetřitelnost nemocných s plicním emfyzémem. Pro diagnostiku CHOPN u osob s CHSS stačí funkční vyšetření plic spirometrií, poměr parametrů $\mathrm{FEV}_{1} / \mathrm{FVC}<70 \%$ u pacientů $\mathrm{s}$ CHSS podporuje diagnózu plicní obstrukce podle tzv. klasifikace GOLD (Global Initiative for Chronic Obstructive Lung Disease).

V poslední přednášce této sekce hovořil prof. Parissis z Řecka o optimální terapii pacientů s CHSS a CHOPN. V léčbě plicní obstrukce u pacientů s CHSS jsou preferována anticholinergika (např. ipratropium) před $\beta_{2}$-agonisty, které zvyšují riziko tachykardie a zvyšují mortalitu pacientů s CHSS. Stejně tak nejsou vhodná analoga teofylinu pro arytmogenní potenciál. Naproti tomu u pacientů s CHOPN, u nichž je zjištěno srdeční selhání, jsou lékem volby inhibitory ACE nebo sartany, které snižují riziko bronchokonstrikce zprostředkované angiotensinem II. Inhibitory ACE prritom nezvyšují u pacientů s CHOPN riziko kašle oproti nemocným bez plicní obstrukce. Spironolakton zlepšuje plicní difuzi. Beta-blokátory se u pacientů s CHOPN méně používají pro obavu z bronchokonstrikce. Ukazuje se však, že léčba beta-blokátory prognózu pacientů se srdečním selháním a CHOPN nezhoršuje, právě naopak. Preferovány jsou selektivní blokátory $\beta_{1}$-adrenergních receptorů, které mají prokazatelně nižší bronchokonstrikční potenciál (metoprolol, bisoprolol, nebivolol).

Následující kongresový den byl velký prostor věnován výsledkům randomizovaných studií, které byly publikovány nebo prezentovány na mezinárodních kongresech $\mathrm{v}$ předchozím

\begin{tabular}{|lcc|cc|}
\hline Studie & $\mathbf{0 , 2}$ & $\mathbf{0 , 5}$ & $\mathbf{1}$ & Odds ratio \\
\hline AREA in-CHF 2009 & & & & 0,50 \\
\hline RALES 1999 & & & & 0,62 \\
\hline EMPHASIS 2010 & & & 0,54 \\
\hline Souhrn (pooled data) & & -1 & 0,63 \\
\hline 0,1 & 0,2 & 0,5 & 1 & 2 \\
& \multicolumn{3}{l}{ Cleland JFG, et al. EJHF 2011,13:460-465 } \\
\end{tabular}

Obrázek 2 Antagonisté aldosteronu - efekt na mortalitu osob s chronickým srdečním selháním roce 2010 . V sekci věnované optimální péči o pacienty s CHSS ischemické etiologie hovořil prof. Ribeiro z Brazílie o významu a výsledcích studie EMPHASIS-HF. Tato studie testovala dopad antagonisty aldosteronu eplerenonu na riziko úmrtí a hospitalizace u pacientů s CHSS ve funkční třídě NYHA II. Ischemickou etiologii srdeční dysfunkce mělo v této studii $69 \%$ pacientů. Do studie bylo zařazeno 2737 pacientů starších než 55 let s CHSS třídy NYHA II, EFLK $\leq 30 \%$ a sérovou koncentrací kalia $\leq 5,0 \mathrm{mmol} / \mathrm{l}$. Eplerenon podávaný $\mathrm{s}$ cílovou dávkou $50 \mathrm{mg}$ denně významně snížil ve srovnání s placebem riziko primárního kombinovaného ukazatele (úmrtí + hospitalizace pro srdeční selhání) po průměrné době sledování 21 měsíců o $37 \%$ (HR 0,$63 ; p<0,001)$, významně příznivě byla ovlivněna i celková mortalita (HR 0,76; p =0,008), riziko úmrtí z kardiovaskulárních prríčin (HR 0,$76 ; p=0,01)$ a velmi významně riziko hospitalizace pro srdeční selhání (HR 0,58; p < 0,0001). Výskyt hyperkalemie $>5,5 \mathrm{mmol} / \mathrm{l}$ byl vyšší ve skupině léčené eplerenonem ( $11,8 \%$ vs. $7,2 \%$; p < 0,001). Na základě výsledků studií antagonistů aldosteronu byla provedena metaanalýza dokumentující konzistentní vliv této lékové skupiny na mortalitu pacientů se srdečním selháním a systolickou dysfunkcí LK funkční třídy NYHA II, III a IV, kteří jsou léčeni inhibitory ACE nebo sartany a beta-blokátory. Dopad antagonistů receptoru aldosteronu na mortalitu pacientů s EFLK $\geq 40 \%$ je hlavním sledovaným ukazatelem probíhající studie TOPCAT.

Kongres byl velice př́nosný jak z hlediska nových informací, tak díky možnosti kontaktu s lékaři-specialisty v problematice srdečního selhání. Ukázal nové perspektivy diagnostiky a léčby akutního a chronického srdečního selhání. Novinky na poli terapie zasahují jak do oblasti farmakoterapie, tak do oblasti přístrojové léčby srdečního selhání. Přiští evropské setkání se bude konat v srbském Bělehradu ve dnech 19.-22. 5. 2012.

\section{MUDr. Filip Málek, Ph.D. \\ Ambulance srdečniho selhání a hypertenze \\ Kardiovaskulární centrum Nemocnice Na Homolce \\ Roentgenova 2, 15030 Praha 5 \\ e-mail:filip.malek@homolka.cz}

\section{Literatura}

1. Kimmenade RR, Januzzi JL, Ellinor PT, et al. Utility of amino-terminal pro-brain natriuretic peptide, galectin-3, and apelin for the evaluation of patients with acute heart failure. J Am Col Cardiol 2006;48:1217-1224.

2. de Boer RA, Voors AA, Muntendam P, et al. Galectin-3: a novel mediator of heart failure development and progression. Eur J Heart Fail 2009;11: 811-817.

3. Lok DJA, van der Meer P, de la Porte PWB, et al. Prognostic value of galectin-3, a novel marker of fibrosis, in patients with chronic heart failure: data from the DEAL-HF study. Clin Res Cardiol 2010;99:323-328.

4. Cleland JGF, Daubert J-C, Erdmann E, et al; the Cardiac Resynchronization - Heart Failure (CARE-HF) Study Investigators. The effect of cardiac resynchronization on morbidity and mortality in heart failure. $\mathrm{N}$ Engl J Med 2005;352:1539-1549.

5. Moss AJ, Hall, JW, Cannom, DS, et al., for the MADIT-CRT Trial Investigators. Cardiac-resynchronization therapy for the prevention of heart-failure events. N Engl J Med 2009;361:1329-1338.

6. Tang ASL, Wells GA, Talajic M, et al. for the RAFT Investigators. Cardiac resynchronization therapy for mild to moderate heart failure. N Engl J Med 2010;363:2385-2395.

7. Dickstein K, Vardas PE, Aurichio A, et al. 2010 Focused update of ESC guidelines on device therapy in heart failure. Eur J Heart Fail 2010;12:1143-1153.

8. Abraham WT, Foreman B, Fishel R, et al. Fluid Accumulation Status Trial (FAST). Heart Rhythm 2005;2(Suppl):S65. Abstract AB33-34.

9. Zannad F, McMurray JJV, Krum H, et al. Eplerenone in patients with systolic heart failure nad mild symptoms. N Eng J Med 2011;364:11-21 